\title{
The cell and the corridor: imprisonment as waiting, and waiting as mobile
}

Sarah Armstrong, Scottish Centre for Crime and Justice Research, University of Glasgow

Abstract: We are likely to think of imprisonment as the exemplary symbol of waiting, of being stuck in a space and for a time not of our choosing. This concept of waiting is perfectly represented by the image of the prison cell. In this paper, I contrast the cell with the less familiar imagery of the corridor, a space of prison that evokes and involves mobility. Through this juxtaposition I aim to show that prisons are as much places of movement as stillness with associated implications for penal power and purpose. I argue that the incomplete imaginary of prison as a cell (and waiting as still) may operate as a necessary fiction that both sustains and undermines its legitimacy. By incorporating the corridor into the penal imaginary, key premises about how prisons do and should work, specifically by keeping prisoners busy, and how prison time flows and is experienced, are disrupted.

Keywords: prison, time, waiting, mobility

\section{Introduction}

Prison is a familiar metaphor of waiting, evoked when we feel stuck, caged, forced by others to endure a period of empty time. This metaphor draws on a literal understanding of prison as a form of waiting. The 'two most essential experiential characteristics of prison time [are] a feeling of waiting and a sense of time as a burden' (Miesenhelder, 1985: 44). Prison waiting may be experienced as particularly burdensome because it stops time (for the prisoner) while the rest of the world moves on; it produces the particular pain of 'time standing still but passing away' (Wahidin, 2006: para. 6.4). Other people wait for something specific and meaningful to happen (a medical diagnosis, the Second Coming, an asylum decision) while prisoners wait merely for the waiting to stop, for their sentence to be complete. This temporality of imprisonment finds its spatial translation in the prison cell where 'time itself [is] compartmentalised through space' (Matthews, 2009: 37). The cell visualises imprisonment as a waiting experience defined by immobilisation.

In this paper I analyse and challenge the cell's dominance as a visual shorthand of punishment, particularly its representation of prison time. The imagery of the cell, reflected in empirical accounts of imprisonment, works as a conceptual metaphor of punishment, forming our basic understanding not only of what it might be like, but fundamentally of what it is, its nature, possibilities and pains (Lakoff and Johnson, 1980). The cell provides a 
compelling and comprehensive imaginary of penality (Carlen, 2008) that encourages us to think of imprisonment as something which contains and immobilises bodies in both space and time. I argue that this imaginary obscures the extent to which imprisonment involves constant circulation, porous borders and unruly time. My aim is to explore the implications of drawing out mobility as an important and even defining aspect of penal waiting, and to suggest that this has consequences for critique and reform of the prison. I will argue that understanding penal waiting as a form of stopped time and stilled movement focuses us on a particular population in prison (inmates who stay for a while) and constructs their needs in particular ways (namely, that they should be made to engage in purposeful activities in designated spaces). The cellular mode of 'seeing' prison thereby ignores many other prison waiters - inmates who come and go, staff and visitors - and blinds us to seeing how prison experiences harm and help those within in them.

In order to develop these arguments, I attempt to give visibility to mobilities in prison by countering the cell's visual and imaginary power with an alternative and missing imagery, that of the corridor. Corridors, hallways, walkways are mundane spaces of constant movement, indeed spaces where movement supplies the spatial purpose. Juxtaposing the corridor with the cell shifts the imaginary of prison from a waiting room to a waiting space, from thinking about imprisonment through the connotations of a specifically bounded place to something that has spatial, but not necessarily fixed, dimensions. This move aims to short circuit the tendency to equate the prison experience of time with that connoted in waiting rooms. It also offers a different vantage point from which to survey a well worn debate about the problem of managing time in prison, by inserting the concept of waiting as the analytic lens through which we attend to this problematic. What is it to wait in prison? Where and how does it happen? The growing literature on waiting has begun to document how waiting can be productive, active and mobile, and some have directly connected this work to mobilities research (e.g. Bissell, 2007). Mobility in prison is a particularly neglected dimension of imprisoned experience, and the spatial metaphor of the corridor opens up our ability to consider prison as a technology of circulation as much as containment. The corridor allows us to see how waiting can be a mobile experience even in society's most monolithic and controlling spaces. 
This is a conceptual piece, a thought experiment, in which I draw on a range of empirical and theoretical resources, as well as my own research engagement with penal practice and policy primarily of contemporary Scotland, where I live and work. I might be tempted to describe the method as a composite account of prison systems with an ethnographic interest in the representations, rather than empirical details, of imprisonment (what I called policy ethnography in Armstrong, 2010; and see Riles, 2006). This piece is situated in and builds on the literature on time and punishment (and the creative spirit of Cohen and Taylor, 1972, one of the few works to focus on the phenomenology of time in prison) but, unlike much of the ethnographic and autobiographical work in this area, does not draw particularly on the voices of the punished in articulating the nature of carceral time (as do, among many others, Geunther, 2013; Medlicott, 1999; Wahidin, 2006; Miesenhelder, 1985; Rhodes, 2004; Mannochio and Dunn, 1970; Brown, 1998). Such work begins with premises that this paper seeks to unpack: about a particular version of time (waiting preconceived as dead, wasted, empty time) and subject (the prisoner as the only actor in prison with the burden of managing time). ${ }^{1}$ After discussing the imagery and implications of the cell as a mode of imagining the prison, the paper shifts to document the ways that prison keeps people on the move and then, discusses how the imagery of the corridor might help us make sense of this as waiting. The final section of the paper suggests how foregrounding the corridor, and circulation, inverts conventional normative considerations and critique of the prison, modernity's exemplary punishment.

\section{In the Cell}

In Foucault's (1995) classic elaboration of modern power, the cell, and the other prison spaces in which the prisoner stops (to repent, work, learn, exercise, eat), are explicit in a timetable, but the corridor, a space of movement and passage between disciplinary activities, is only implied. Within the two-page excerpt of the prisoners' schedule in Discipline and Punish is a single reference to a space and time of circulation: 'There is a five

\footnotetext{
${ }^{1}$ As Miesenhelder (1985: 44) quotes Goffman's classic work Asylums: 'among inmates in many total institutions there is a strong feeling that time spent in an establishment is wasted or destroyed or taken from one's life'.
} 
minute interval between each drum roll' (Foucault, 1995: 6). ${ }^{2}$ A copious literature documents the functions, effects and lived experience of destination spaces within prison (work rooms, exercise yards, dining halls), but the same cannot be said of the processes of circulation between them, nor of the wider circulations of individuals inside and between prisons, and to other institutions (with some important exceptions, e.g. Moran, Gill and Conlon, 2013; Wacquant, 2001).

The cell is deeply embedded in collective memory as the crucial space of incarceration. It is allied to, and descended from, other 'coercive spaces of segregation' (Matthews, 2009: 25) - monasteries, barracks and asylums (Goffman, 1961; Foucault, 1995). The cell is where prison's purpose, and purposelessness, can be found: in penitence, boredom, suicide. Influential theories of power draw primarily on the iconography of this carceral space. Foucault envisions the cell within the Panopticon as the exemplar of modern power, training and producing the disciplined subject who sits under the assumed gaze of an authority figure. The prison itself often is depicted metonymically as a cell, a space apart in which a prisoner's 'free life in society has been suspended' (Medlicott, 1999: 211). It is the basic building block of social (and bio) power.

The cell makes visible a key function of the prison, possibly its least disputed purpose: confinement (but see Jefferson, 2014). Like all metaphors, however, the cell is at once 'a way of seeing and of not seeing', of prioritising some qualities of imprisonment over others (Eldridge, 2014, and see Schön, 1981). The cell shows us the experience of penal time through the imagery of the waiting room, an experience to which all can relate. The cell thus provides a readily legible symbol of the universal experience of enforced boredom and stillness, but in this comparison arguably under and misrepresents much of the experience of waiting in prison, not least in assimilating unbridgeable scales of intensity and duration of waiting, say, in a doctor's office compared to waiting out a prison sentence. A second feature of the cellular imaginary is that spatial, not temporal, considerations become the paramount dynamic to be managed, as the psychic pain of lost time is translated as the physical pain of enclosed space (Matthews, 2009). Prison staff face the challenge of

\footnotetext{
${ }^{2}$ This timetable is reflected in many prison regimes of our own times with many examples to be found such as this random selection from Ireland produced by a Google search of 'prison timetable' in July 2014: http://www.citizensinformation.ie/en/justice/prison system/prison timetables in ireland.html
} 
maintaining order and security while prisoners face that of maintaining sanity and physical safety in monotonous, threatening and squeezed spaces (Geunther, 2012; Rhodes, 2004). Coping with time is not a unique pain imposed by prison compared to other forms of punishment, nor is spatial confinement an inherent feature of 'timed' sanctions, though it may appear to be given the prominence of prison in our social imagination. Counter examples include electronic ankle tags and probation, both sanctions meted out in temporal units (one is sentenced to so many hours or months 'on the tag') but complied with not necessarily by adherence to a space, but completion of an activity (such as a drug treatment course, showing up to meetings).

Finally, the cell imaginary situates us as viewers of punishment in much the same way that audiences are positioned by television and stage behind the invisible fourth wall, looking in on the action (see Lam, this issue). This positioning produces a particular visibility of punishment that furnishes our social imagination of penal possibility. Debates over the rightness or wrongness, softness or hardness of prison often revolve around what the inmate is getting up to in his cell (or not getting up to in a prison classroom or work shed). These debates are historically situated; for example, in the early years of the American penitentiary (i.e. up to the mid-19 ${ }^{\text {th }}$ century) concern circled around different ideals of cellular isolation, as a place for silent penitence or a work space where inmates should be kept busy in cells through piecework (Rothman, 2002). Both the still and active ideals of punishment played out in and were circumscribed by the spatial segregation of prisoners into individual cells. ${ }^{3}$ Our own times have been influenced, in the US and UK, by $20^{\text {th }}$ century progressive ideas of rehabilitation and a more recent 'populist punitivism' which seeks to make prison as unpleasant and punitive an experience as possible (Pratt, 2000). While these forces often are taken as contradictory, together they have swung the pendulum towards a contemporary view that imprisonment should be active. The progressive liberal and regressive conservative might come together in outrage at prisoners allowed to sleep all day, stare into space, watch television, shaking their heads at, respectively, the neglectful or soft hand of justice. The punishment of time, as spatialised through the cell, gives us a myopic, and sometimes literally a peephole, view of imprisonment in which we 'see' and

\footnotetext{
${ }^{3}$ The shared ideal of such solitary confinement was, as scholars have noted (Rothman, 2002), confounded by the reality of overcrowding in cells parts of the jail.
} 
therefore understand penal time as sitting around. This undergirds and makes sense of the perennial calls for imprisonment to be active and goal focused. Time must be done and not merely passed. ${ }^{4}$

I am analysing the cell per se but also, in making the case of it as the dominant symbol in a social imaginary of punishment, using it also as a synecdoche or archetype of other prison spaces: dining hall, recreation area, classroom, visiting centre, hospital wing. In all of these, the inmate is watched, guarded and constrained in movement. Each space comes with its own timing, function and rules. One cannot exercise during a visit, eat during an anger management class or shower at midnight. The overall architecture and visualisation of control is the same, however, to manage order and assign to each space its purposeful activity. Hence, the swirling flow of life is broken up by the cellular prison into boxes of time in which particular activities are authorised, or not. In the modern prison, cellular slicing up of life into spatio-temporal boxes is then linked in a linear narrative of punishment as an institution of security and rehabilitation. The two graphics in the figure below are taken from a recent strategy document of the Scottish Prison Service (SPS, 2013). In it, rehabilitation is constructed as the product of the accumulation of discrete activities including healthy eating, regular exercise, family contact, offender behaviour courses and job training. Each of the graphics displays key elements of the cellular imaginary, rendering them as the cells of the organisational chart.

\footnotetext{
${ }^{4}$ Echoing Thompson: 'Time thus became currency and was "spent" rather than "passed"' (EP Thompson 1967: 61 , quoted in Rotter, this issue).
} 
FIGURE 1

Figure 4.4: Model of Community Transition
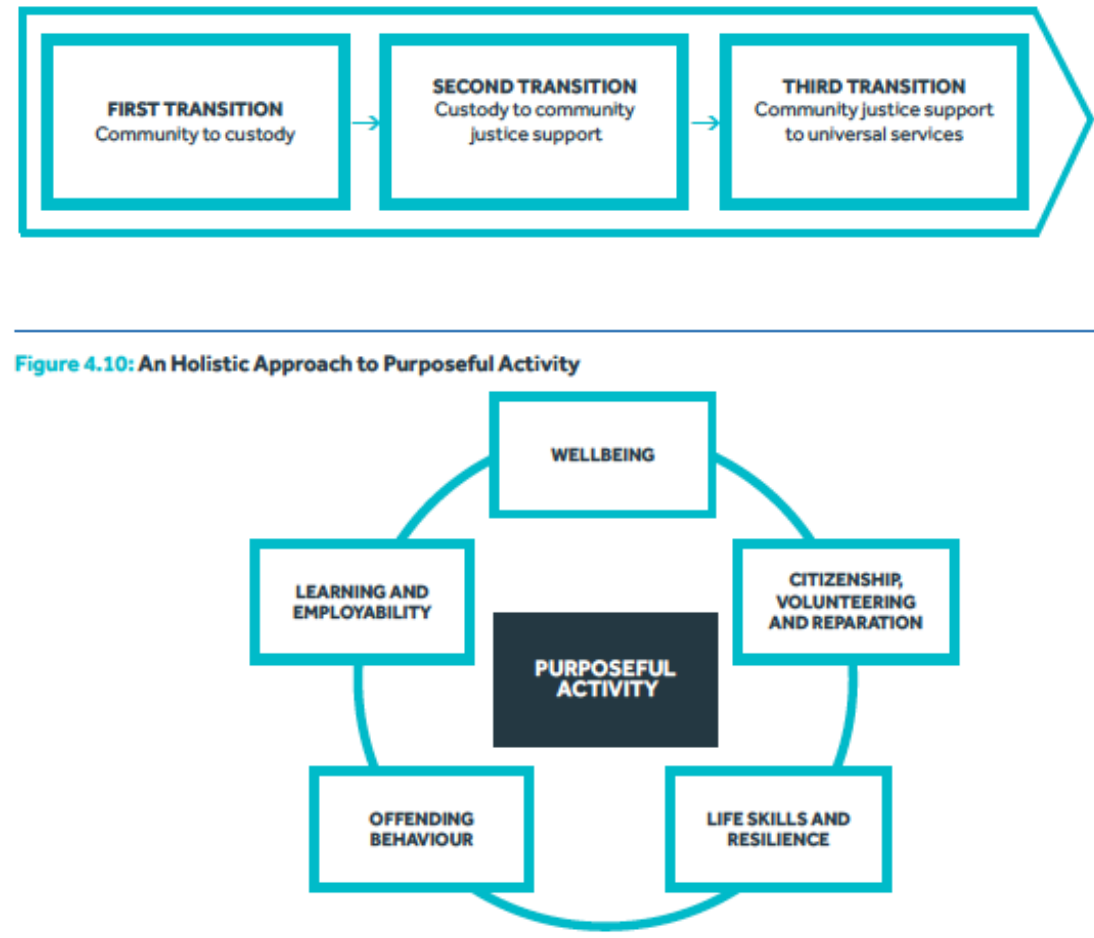

(Scottish Prison Service, 2013, pgs. 64, 86)

One after another, activities are set out in a timetable or a flow chart, driven by an official logic of progress. The logic of control expressed in such official documents reveal a Foucauldian penal power in which '[w]e...become disciplined through the waiting process' (Kohn, 2009: 225). The cell is at the heart of this account. It isolates the body in space and time making it available to be produced and trained as an individually disciplined subject. For Foucault the cellular arrangement of the reformatory controls subjects by controlling time, creating 'a new way of administering time and making it useful, by segmentation, seriation, synthesis and totalization'; it constructs 'a linear time whose moments are integrated, one upon another...a social time of a serial, orientated, cumulative type: the discovery of an evolution in terms of "progress"' (Foucault, 1995: 160). This narrative enlists time to discipline docile bodies; the physical organisation of the prison into cells is essential to this. 
Popular culture as well as research abound with representations of prison that dwell on and reproduce waiting as a spatial phenomenon. Such images reflect a cell imaginary that encourages us to see prisoners as immobile, trapped in space symbolising 'suspended lives' (Medlicott, 1999). As the key site of action (or inaction), the cell thus organises description, critique and reform of the prison. What remains missing from the picture is flow: how people get into, out of and around prison; how much time is wrapped up in movement; how disciplinary, painful, reforming processes play out beyond the cell, the classroom, the rec yard.

\section{FIGURE 2}

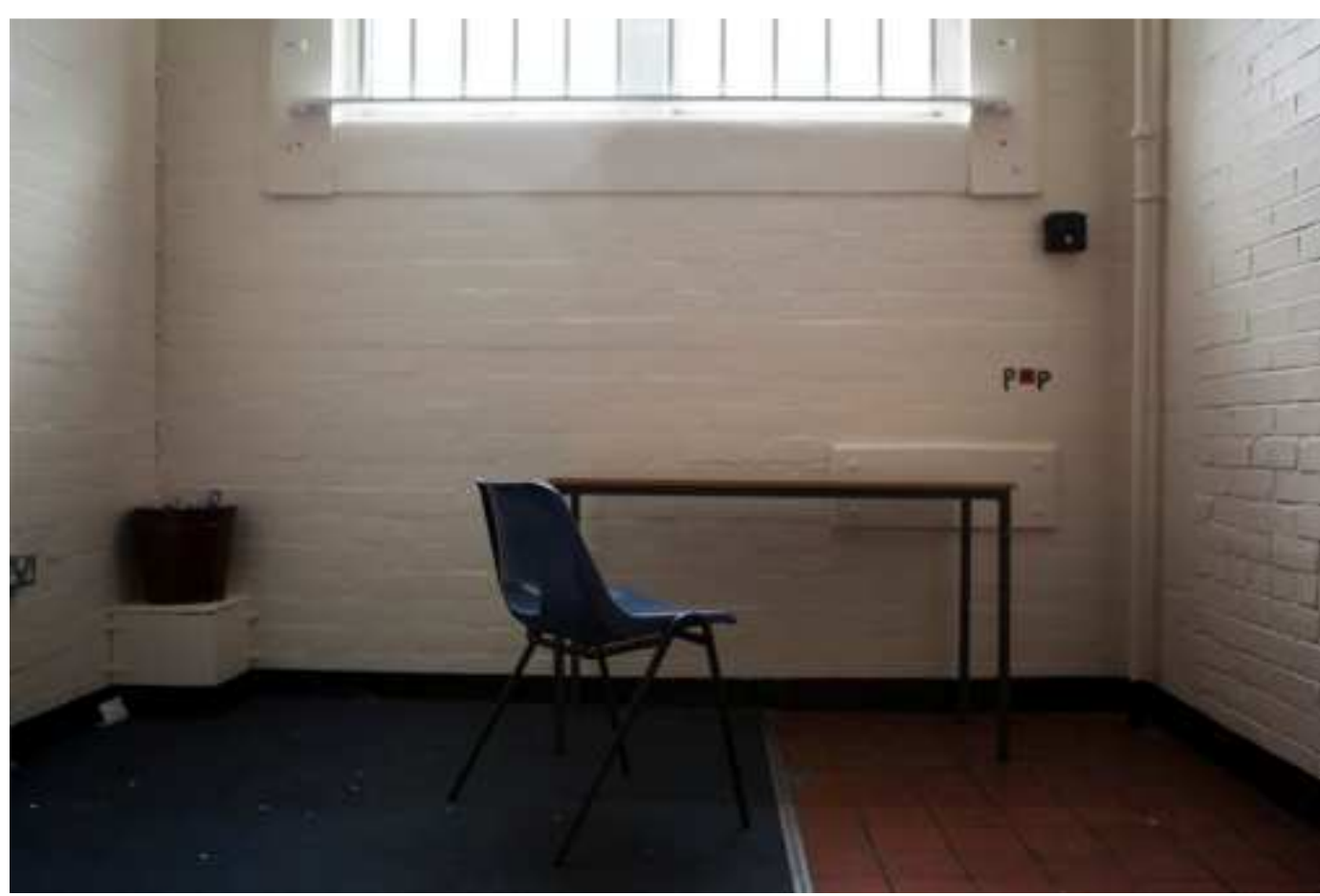

Copyright Jenny Wicks, 2012

\section{On the move}

A cellular imaginary evokes the "stasis and stagnation implicit in the term "waiting" (and popularly associated with the notion of incarceration)' (Kohn, 2009: 218). But if we centre waiting as the problem to be explained, rather than as an unexamined description of imprisonment, we might open up some new perspectives on prison and time. 'The analytic power of waiting...derives from its capacity to highlight certain features of a social process that might have hitherto been foreshadowed by others or entirely hidden' (Hage, 2009: 4). 
Who waits in prison? How do they wait, and how does the waiting affect them? From the vantage point of asking these questions it is possible to see many kinds of activity, still and mobile, in and around prison.

Over a decade spent as a researcher moving through, documenting and studying the penal system in Scotland informs my sense that waiting in prison is composed both of mobility and immobility. Here is a composite account of a typical criminal justice journey: If a prison sentence is on the cards, you are likely to be on remand already. ${ }^{5}$ The many affective dimensions of waiting for your case to be adjudicated (boredom, frustration, hope, fear; see Reed, 2010) accompany both still waiting in a cell and regular movement back and forth between jail and court in a secure van and back and forth between cell and meetings with your lawyer. The typical amount of time spent on remand in Scotland is 23 to 24 days so you will see many others come and go, just as you have come and soon will go once sentenced or acquitted (Scottish Prisons Commission, 2008). If convicted, there will be a move to a different prison or a different part of the prison to serve out time. The start of this sentence is marked by isolation in a separate, reception cell as risk is assessed and various other induction processes are carried out. Eventually, one is moved to more permanent housing with access to different parts of the prison. Prisoners move back and forth to attend visits from family and friends, meet with drug counsellors or religious services, use the library, attend the gym or education and so on. These form part of the daily rhythms that comprise the regimented and repetitious movements inherent to the institutional management of large populations. Alongside daily movements are rhythms orchestrated by one's sentence length, which will determine eligibility and availability for courses and involve additional moves around or between prisons.

Even those prisoners who might exemplify the cellular imaginary of stillness - the long term and life sentenced - are regularly on the move. Though their time cycles are less compressed than short term inmates, the repetitious daily circulations are identical. They, too, will transfer from remand prisons to sentenced prisons, but in addition often circulate through a series of institutions (e.g. those designated for 'sex offenders' or where particular

\footnotetext{
${ }^{5}$ More people enter prison in Scotland on remand, to await a trial or sentence, than to serve a sentence (Armstrong, 2009).
} 
courses and interventions are offered) and back again or to open prisons as they near the later stages of a sentence in what prison officials refer to as 'progressing to liberty'.

All prisoners can also be moved about over the course of their sentences for many other reasons including: 'population management', a term of art referring to keeping within building capacity limits (Armstrong et al., 2011); for disciplinary reasons or sometimes specifically as a punitive measure (Gill, 2013); medical reasons; court appeals; revised risk assessments; new offending; for their own protection; to be closer to family. In the words of a senior manager who sat next to me as prisoners served us lunch: 'See that guy over there? We started in the Prison Service together up at Perth [prison] nearly twenty years ago and now he's here. I stayed there longer than he did. Prisoners don't stay in the one prison any more, they move about. ${ }^{6}$ Prisoners may make more exceptional moves to isolation (punitive segregation) or suicide watch cells. These circulations can be frequent but irregular, and often experienced as painful. Prisoners may be moved from cells, wings and prisons without any warning or understanding of why they are moving. It is not just sitting still, but the monotony of both routine and unpredictable circulations that creates the pain of punishment. On the former, a prisoner in Wahidin's research (2006) says: 'Time has stood still in that everything goes on and on in the same repetitive way. It is as if the nineteen years could have all been fitted in one year....Every single day is the same. It drives you mad!' (Para 6.8). The linearity of past, present and future for the prisoner dissolves into a plurality of oppressive temporal scales of numbing repetition within the day and variability over the sentence. This particular dynamic of time might be compared to the orbit of Venus, where a day is longer than a year. These different examples of waiting and mobility in prison reveal temporal flows which are multiple, nested, circular, distorted, painful.

A key difference in focussing on waiting rather than on imprisonment is that it allows us to see more actors than the inmate as prison's 'waiters'. Solipsistically, the experience of prison research comes to mind. Researchers buzz to get in, sit and wait to be called and deposit phones, proceed to the gate and wait to be called for passage through the next gate. We sit and wait for the guard to let us through. Sit and wait in an interview room for a

\footnotetext{
${ }^{6}$ This comes from an informal conversation between myself and an SPS manager during research on another project (Armstrong et al. 2011). I made a note of it at the time feeling it was important somehow, and seeing now it was destined for this work on waiting!
} 
prisoner to be brought for interview (or visit), passing back and forth between interview room and break room. Then the process reverses to get back out of prison, to sit and wait for a train to return to offices and homes. To gather around 20 hours of recorded interview data for one project (Armstrong and Weaver, 2013), I estimate that over 100 hours were taken up working on and waiting for ethics approval, prison approval and finally prisoner consent (to be interviewed); this waiting involved much doing and moving (working on, an important theme of the waiting literature that is absent from accounts of imprisonment (Kohn, 2009; Bissell, 2007; Gasparini, 1995; Elliot, this issue). Prison managers and service providers also move regularly, from prison to prison and to prison $\mathrm{HQ}$ for meetings, on secondments as they wait on promotion, court decisions, policy change. Prison guards do a lot of waiting, too. A certain portion of any given shift's staff complement is available for prisoner escort - to move prisoners between meals, visits, appointments, research interviews. They stand around in between these times making cups of tea and small talk. And finally, as noted, prison waiting does not only happen within the prison system but is imposed also on families whose time is partly stopped but also marching forward as they carry on with their lives while waiting for a relative to re-emerge. Prisoners (and for the most part the prison's other habitués) have little control over the movements and timings dictated by the spaces, scales and institutional agencies that arise in penal settings.

In sum, the prison is crossed by heterogenous and multiple time cycles that involve journeys of waiting around and between spaces, inside and outside the prison's gates. Like water forming an arc over a rock in a stream, these journeys compose a stable object made of ephemeral moving parts. Such flows reaffirm the immobility of prison as a built space and an institution of control - the rock that determines the direction and shape of the arc - but produce specific social realities in need of investigation. The cell imaginary veils these multiple actors and diverse time rhythms of prison waiting. The cell encourages us to treat the animal in the cage as the only actor in the drama whose time is fixed by punishment. Waiting is not just something that happens in locked cells, but flows through and out of the cell and in between spaces of designated activity. Circulation then is a core aspect of waiting in prison.

How does mobile waiting play out, how might it extend the pains or possibilities of punishment? This is not the first paper to consider these questions, nor the first to observe 
that confinement entails movement. Others have documented how prison literally and psychically dislocates people from places and relationships (e.g. Pallot and Piacentini, 2012, depict the transport journeys of women prisoners across Russia). Hiemstra (2013) maps the institutional journeys across the vastness of the United States of those accused of illegally migrating, quoting one informant for her title, 'you don't even know where you are'. These dislocating, exiling effects might be intentionally sought, and a number of writers have discussed imposed movements within and between prisons as an intentional strategy of punishment (Gill, 2013; Matthews, 2009). These accounts allow one to see that the water between the islands is an essential part of the disciplinary element of Foucault's 'carcercal archipelago'. It is interesting, though, that these pains of carceral mobility often are presented as enhancing or supplementing the ordinary pain of imprisonment, implying that the 'normal' state of imprisonment is having a predictable sense of where and for how long one will be in prison; in other words, a sense of prison time that re-confirms the spatial model of cellular stillness. ${ }^{7}$

One theorist who has focused on circulation as a site of control is of course, Deleuze. His essay on control societies excavates the importance of circulation for modern power. He sets up his account in direct contrast to Foucault's in Discipline and Punish (to which he positions his essay as a 'postscript'): circulation, Deleuze argues, is not merely the means of getting from one disciplinary enclosure to another, but contains the essence of social control itself. '[In] societies of control one is never finished with anything...perpetual training tends to replace the school, and continuous control to replace the examination' (Deleuze, 1992: 3). Foucault, in contrast, set his theory of power within the institutions of modernity that could 'initiate vast spaces of enclosure. The individual never ceases passing from one closed environment to another, each having its own laws: ...the school...the factory...the barracks...from time to time the hospital, possibly the prison....Their ideal project is... to concentrate; to distribute in space; to order in time; to compose a productive force' (Ibid.). But Deleuze faults Foucault's account as missing out on the disciplinary effects

\footnotetext{
${ }^{7}$ Birkbeck and Perez-Santiago (2006) point out both the taken-for-grantedness of such a view of prison timespace in many accounts of prison, and that such an attitude of linear, predictable punishment time is a peculiarity of Western cultural norms that are not shared in other places, in their case, South America. In addition, the cellular foundation of prison architecture and management is also a specifically American and European development. Reed (2010) and Martin (2013) have noted group styles of living (e.g. dormitories) in non-Western contexts.
} 
of moving between and around institutional enclosures. The key point of disciplinary institutions like prison (or schools, hospitals, families and factories) is not in the production of an ideal subject, impossible in practical terms, but the creation of an ideal that can never be realised. This paradox of the unachievable aspiration is productive because it authorises never ending processes of control. The prison serves not to rehabilitate (to produce once and for all law abiding citizens) but merely to mark an individual as in need of a particular style of intervention and control throughout their lives in the same way that employees and students are subject to continuous and continuing training and certification. In sum, Deleuze offers an account in which circulation itself is central to understanding the nature of power, where 'moulding' the individual within the institution gives way to a system in which individuals are exposed to infinite and infinitely ratcheted 'modulations' of continuous processes. The distinctive quality of control through circulation lies in its assertion that the individual will always require intervention - she is never fully cured, reformed, trained, qualified or authorised but will always benefit from or require some additional intervention. She must always be kept on the move.

\section{Along the Corridor}

If circulation is a mode of control and a site of pain, how can we make it visible? What would happen to our understanding of penal time if we did? I turn now to the space of the corridor as a counter imagery to cellular waiting, considering the literal and metaphorical dimensions of the corridor and its potential value as an analytical lens. In literal terms, corridors are mundane and familiar spaces. Walking along them brings to mind 'waiting's "special orientation with time" - its only meaning lies in the future "arrival or non-arrival" of the object of waiting' (Kohn, 2009: 225 quoting Crapanzo, p. 44). The corridor thus also materialises the translation of time as space but unlike cells (and their associated spaces), are not themselves destinations. The waiting experience of corridors can be mobile or immobile and is part of both banal and life changing journeys in and through prison. One might wait in a hallway until a guard arrives to unlock a door, but also experience moving along the corridor as waiting, waiting in anticipation of the thing that sits at its end. Corridors move people and things into, around and out of the prison. They are sites of quotidian and extraordinary journeys: taking the prisoner every day to the dining hall, and only once to the death chamber. Corridors as spaces of waiting encompass and symbolise 
many of the prison's temporal scales and their differing affective registers. And significantly, the corridor allows for imprisoned waiting to be conceived as movement.

\section{FIGURE 3}

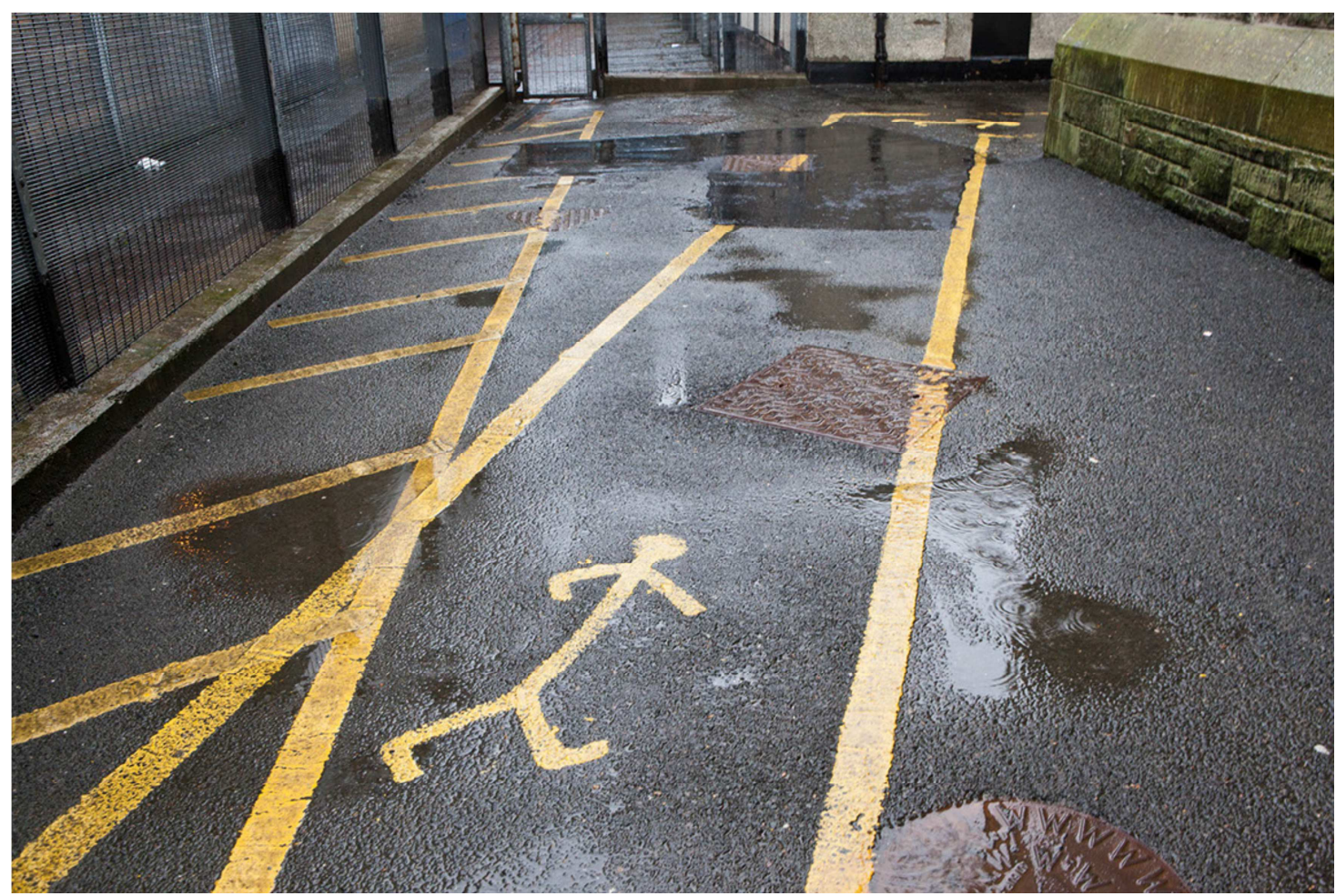

Copyright Jenny Wicks, 2012

A key quality of the corridor is the diversity and mingling of its users. Only one kind of subject is normally visible in the cell - the prisoner, whose isolation is symbolic of the organisation of the prison into sections and buildings that segregate based on the classifications of gender, conviction status, sentence length. Corridors do not discriminate between kinds of prisoners, or for that matter between prison roles. Not every prison denizen sleeps in a cell, but everyone moves through a corridor. Unlike cell design, the corridor lacks specialisation, perhaps because its purpose is so basic and singular: everybody needs to get somewhere.

This is not to say that corridors are spaces of free and open assembly or that they are not complicit in the unequal social relationships produced by prisons. Corridors, like any other built space, communicate a social purpose and narrative (Yanow, 1998: 215). The corridor communicates, inevitably, the power of the institution. It displays and enacts hierarchy by channelling prisoners in ordered lines and escorted by guards. The corridor creates yet 
another opportunity for the prisoner to be tested, monitored and disciplined and it reminds the non-prisoner about the nature of the institution. The painted walkway lines at HMP Barlinnie, pictured above, and the metal sheets preventing one from seeing the rural landscape in which HMP Shotts is set, in the image below, visually warn against stepping (or gazing) out of line (and note the cameras lining the route). While the prisoner is the justification for these security measures, all users of the corridors adhere to them. I feel compelled to stay within the painted lines of prison walkways, and am escorted by staff who do the same. No one, no matter how powerful, runs (skips or hops) down a prison corridor.

\section{FIGURE 4}

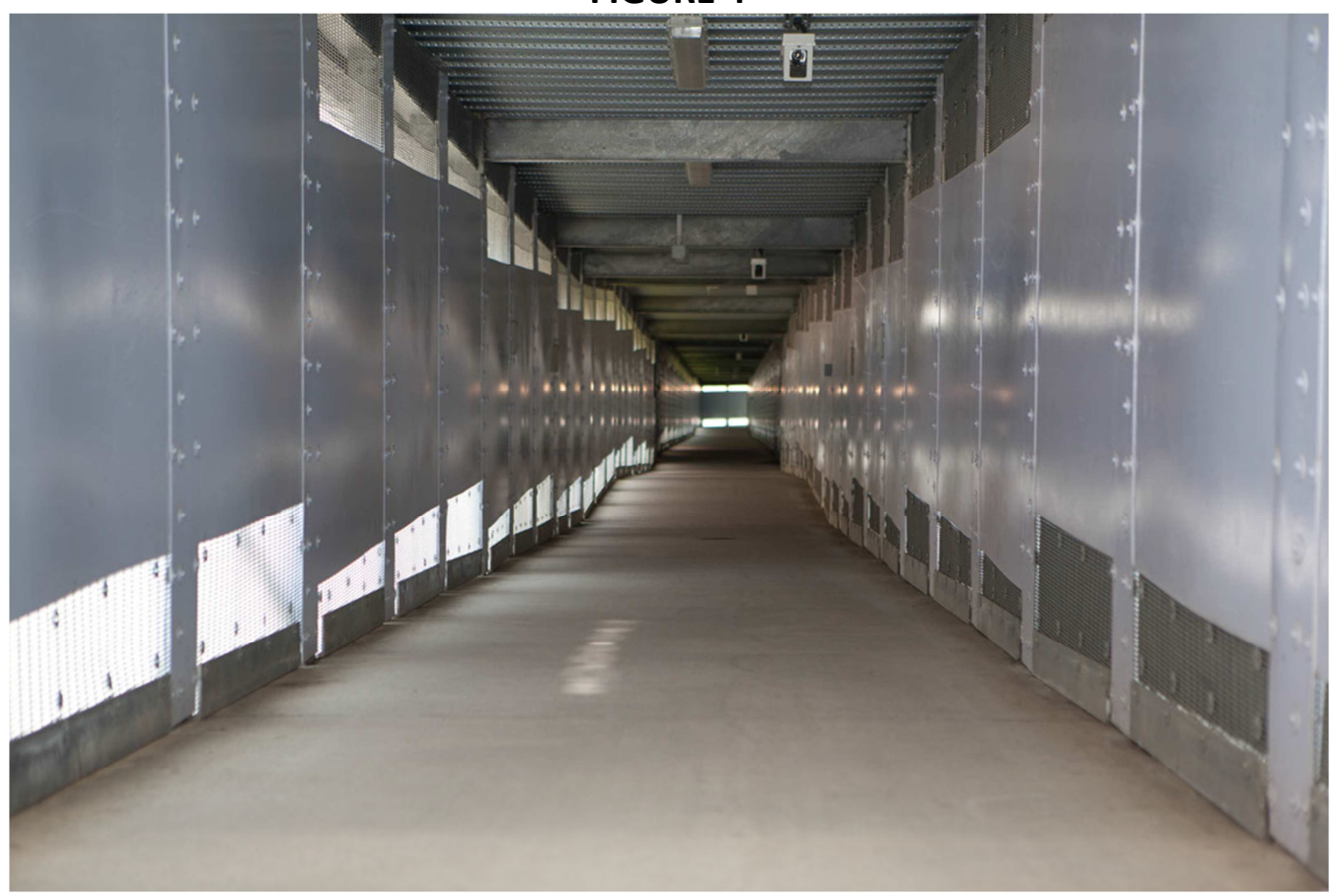

Copyright Jenny Wicks, 2012

The prison corridor is not conventionally thought of as a place where the work of punishment is done. Corridors are side spaces, of getting to and from somewhere else. They are neither meaningful nor meaningless; no activities are scheduled in corridors. But spaces of circulation are central considerations in prison architecture, their design and positioning recognised as crucial to security and control (Matthews, 2009: 32-33). One value of adding the corridor to the carceral imagination is the restoration of movement and circulation as ordinary rather than exceptional qualities of punishment, showing how mobility is embedded in, rather than the binary opposite of, immobility (Bissell, 2007). 
A prison might be thought of as a 'universe ... filled with corridors and antechambers in both a literal and a metaphorical sense' (Phillips, 1998: 28). The quotation refers to the works of the infamous Marquis de Sade, who had some experience of imprisonment and writes about corridors as disorderly, secret places literally outside the functional spaces of rooms and metaphorically 'outside social and moral convention' (Id.: 32). Attending to the figurative role of corridors makes it possible to analyse not only their own disciplinary style but also their potential to disrupt the official narrative of punishment.

As a space 'outside' the places of normal social interaction (and surveillance), the corridor creates potential for anarchic, deviant behaviour in that it falls outside the gaze of social control (Id.: 36). Sade's grotesque protagonists look in on the conventional activities of the salon and the ballroom, literally hidden and metaphorically excluded in corridors and cupboards, and thus free to engage in perverse behaviour. The furtive and outside status of Sade's corridor can subvert understanding of the prison as a site of control. It illustrates the potential of side spaces, movement and fleeting interaction to be productive of social relations. Such a possibility challenges the authority and narrative of prison which vest power exclusively in purposive spaces. Corridors also are excluded from reform and critique, exiled as technical design problems, because they have no role in discourses of rehabilitation or retribution. They display the prison's bare function to control movement. Centring the corridor belies the claim that imprisonment does something with and to people beyond shuffling them around until their time is up. As a metaphor for imprisonment, the corridor provides a needed space outside conventional values and accounts, storing the stuff 'of our worst nightmares [but] necessary and safe (because imaginary) spaces of cathartic play, situated at the very edge of sanity beyond the real and its moral dimensions' (Phillips, 1998: 36). The corridor frees us to see the unseeable and to think the unthinkable (Drake, 2014).

I conclude this section by exploring the corridor imaginary, considering through one example how it might reveal the formerly unseeable. Statistical representations of prison population might be thought of as artefacts of a cellular imaginary. They tend to report prison populations statistically and statically as 'average daily populations' (the total number found in prison on any given day averaged over a year). This approach equates the single prisoner serving a year with twelve prisoners serving a month each - the one and the 
dozen occupy the same space of the table cell and time of the prison cell. But one is not the same as twelve, nor is the impact of one prison sentence - on a person, their family, society - the same as that of twelve prison sentences. In the figure below the 50 people taking up cell space under the sentence category 'Less than 3 months' in 2011-12 are actually 1,756 people passing through during the course of the year (Scottish Government, 2012). ${ }^{8}$

\section{FIGURE 5}

Average daily population of sentenced offenders by sentence length: 2002-03 to 2011-12

Table A.3

\begin{tabular}{lrrrrrrrrrr}
\hline & $2002-03$ & $2003-04$ & $2004-05$ & $2005-06$ & $2006-07$ & $2007-08$ & $2008-09$ & $2009-10$ & $2010-11$ & $2011-12 \%$ change over \\
past year
\end{tabular}

Source: Scottish Government (2012)

The people in the corridor regularly outnumber those in the cells by ten, twenty times and more. If the prison were re-imagined as a corridor we could, and would have to, find ways of giving presence to the 1,756 and not merely the 50 , to understand how these prisoners - who are mainly invisible in projects of design, reform and research - relate to and are affected by the contact they have with each other, their families, prison staff and others. We would see their waiting time as real as the waiting time of a lifer. This is only one way that a focus on the occupants of a cell, and research shaped by the cell imaginary, misses both quantities and qualities of prison experience.

\section{Passing through}

Among the worst things prisons do, according to a large body of critique, is acting as no more than a warehouse of human beings. In this final section, I propose one unthinkable thought, that using the prison as a warehouse, as a short term container of human stock, could be actually its most normatively desirable function. Such an idea becomes thinkable

\footnotetext{
${ }^{8}$ Put another way, on average 50 beds (cells) per year are used by people sentenced to less than three months in prison, and over 1,700 people slept in these 50 beds (were received into prison to serve this sentence) during the year 2011-12. This is using prison receptions data - the number of entries into prison on a particular sentence - as a proxy for the number of human admissions; these figures don't exactly overlap as one human being might account for more than one reception (e.g. someone serving two sentences in a year or transitioning from a remand sentence in one prison to a sentence at another).
} 
by re-framing imprisonment through the concept of corridor time. The human warehouse accusation is normally deployed as a self-evident marker of prison's failure. 'Doing nothing' but warehousing inmates is a failure, however, only if we have accepted that the prison's appropriate purpose is to 'do something' with prisoners that assists them to become better (and better behaved) people - through treatment, training, reflection, classes, punishments. The acceptance of such a premise derives from the success of the cell imaginary in convincing us that the punishment of time (a fixed loss of liberty) is best understood and practiced as a confinement, in a particular style and use, of space. ${ }^{10}$

Let us think instead of the corridor, which presents mobility and movement as normal, central functions of imprisonment. The corridor envisions the prison as a technology of circulation and Deleuze's ideas here about control are important. If circulatory processes effect control by marking people and tracking them into particular routes and subjectivities (the mentally ill person, the offender, the student), then understanding the details of this process in prison requires us to see and account for all the people passing through. A corridor imaginary suggests the prison is, or ought to be thought of as, more institutionally similar to train stations and warehouses - intermediate and mediating spaces rather than destinations - than to schools and hospitals.

The mobilities literature (Urry, 2007) provides a trove of conceptual and empirical resources for thinking this idea through. In Laura Watts' (Watts and Urry, 2008) ethnography of train travel, the shared experience of commuting (which involves a simultaneous mingling of mobility and immobility) diversifies through the range of activities travellers engage in to produce distinctive waiting experiences. The imagery of the corridor visualises and centres a between-time and between-space as an interstitial site of meaningful social activity and therefore empirical interest (and see also Gasparini, 1995). In contrast, prison writing often positions the corridor as subsidiary to the real activity that happens somewhere else, as one prison Governor wrote: 'the corridors remain bleak, transitional places, a no man's land betwixt prison and community' in need of 'brightening

\footnotetext{
${ }^{9}$ http://www.theguardian.com/society/2012/jul/19/prisoners-warehoused-without-uk-rehab-1v is one among hundreds of headlines produce $d$ in Googling 'prison warehouse' (accessed 22-09-14).

${ }^{10}$ Both Deleuze and Foucault present their accounts in the context of capitalism, and the time implications of this have been central to social theory (e.g. Thompson, Giddens) though there is not space to get into this here though the penitentiary mode of social organisation of course is linked to the workhouse.
} 
up' to support the rehabilitative work of the institution (Bennett, 2010: 51). Watts' ethnography challenged one of the most self-evident aims of Government transport policy that commuting time should be minimised. Watts showed people using their commutes in emotionally and materially productive ways. In the same way, we might explode assumptions about the proper scope of penal policy in thinking about how to see hallways as more than transitional spaces in need of brightening up, but as literal sites of human action and oppression and as imaginative resources that can fundamentally reframe understanding of prison space and time. Cellular spaces hold people still and their waiting is made productive by organising time in them, through offender treatment programmes and work training modules and education classes. Corridors move people along and interaction happens in passing. The challenge for research is to hold this movement still, to make it possible to notice the often ephemeral and minute power and effects of passing through alongside those of standing in place. Corridors, both literal and symbolic, contain opportunities, resources and power ripe for empirical study (ledema et al., 2006). A corridor imaginary upsets the logic and risks the order of a prison where only those inmates standing still can be seen, counted and disciplined.

\section{FIGURE 6}

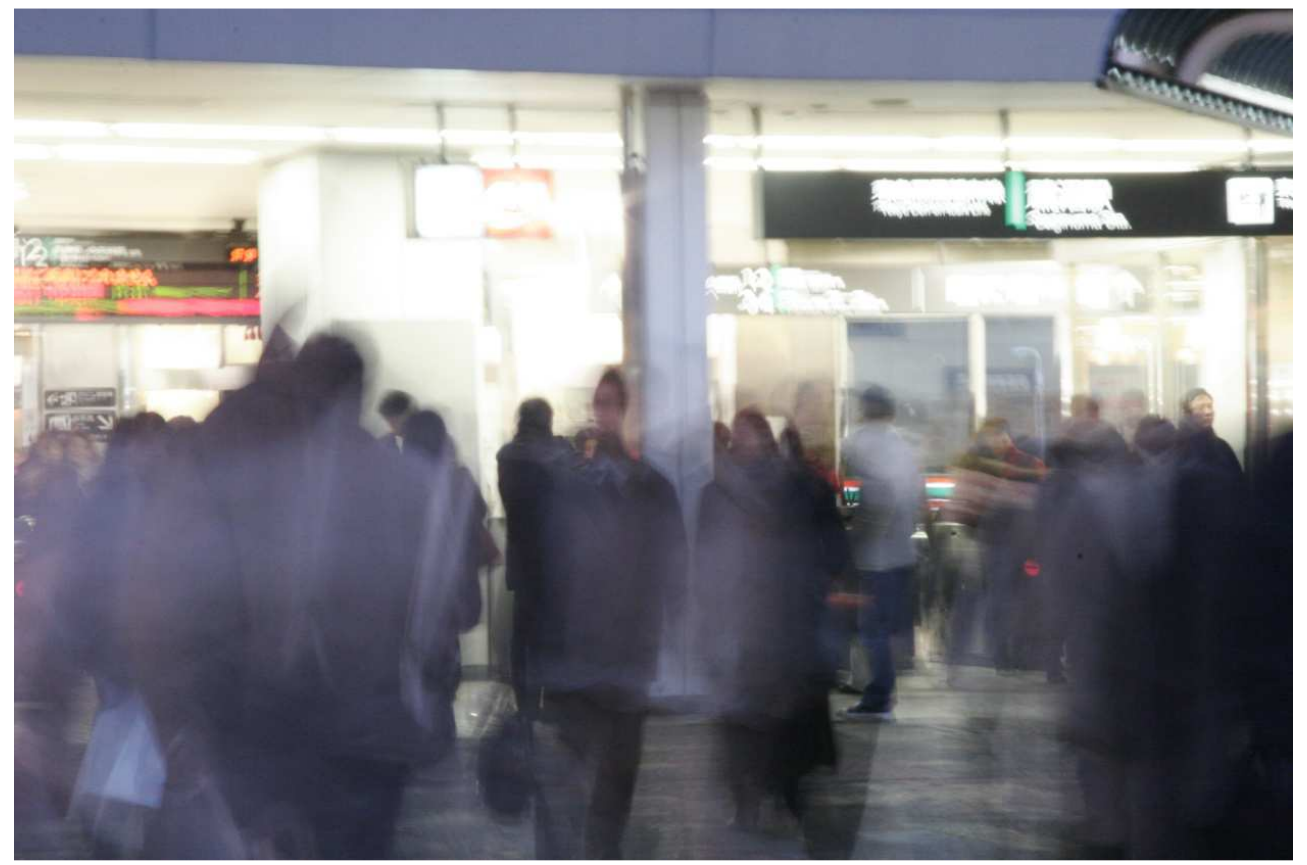

Source: Morguefile, http://mrg.bz/zyAtvR, open access free stock photos 


\section{Conclusion}

We need to break the chain around the prison stuck in our minds, and I have argued this prison is a construct of a cell imaginary, a site of stillness in which the natural response is to impose activity and purpose. If we see movement and activity instead already built into the prison story we might find new routes into a project of critique that doesn't lead us to harmonise with the refrain of prison's apologists: if only we could make waiting in prison more useful, it would be more humane. This uneasy alliance between those who seek fundamentally to criticize and those who seek, as practitioners and policy makers, to make it effective might finally be broken. We might then stop finding ourselves coming up with ideas whose policy translation seems inevitably to argue we should hang onto people for longer and in more isolated spaces in order to have the time we need of making them well or good. As Stan Cohen found:

'the penological and criminological literature depends on proposals for change, and in making them critics are drawn into an inevitable relationship to the rhetoric they hope to "pierce." "Every attempt I ever made to distance myself from the subject, to criticize it, even to question its very right to exist, has only got me more involved in its inner life"' (Rhodes, 2001: 70, quoting Stan Cohen).

This is the imaginary in which the cell is complicit and from which the corridor might lead us, finally, to an exit. 


\section{References}

Armstrong S (2010) Prison's prisms: policy's objects in Scottish penal reform. Conference Paper. Interpretive Policy Association Annual Meeting (June). Grenoble, France. Available at: http://www.esrc.ac.uk/my-esrc/grants/RES-000-222881/outputs/read/c223da76-4a78-4d32-86ee-d8f5c2b22cd5

Armstrong S (2009) Fixing Scotland's remand problem. Research Report, SCCJR No. 02/09. Available at: www.sccjr.ac.uk.

Armstrong S and Weaver B (2013) Persistent punishment: user views of short prison sentences. The Howard Journal of Criminal Justice 52(3): 285-305.

Armstrong S, Malloch M, Nellis M and Norris P (2011) Evaluating the Effectiveness of Home Detention Curfew and Open Prison in Scotland. Scottish Government Social Research Report No. 32/2011. Edinburgh: Scottish Government.

Bennett P (2010) Security and the maintenance of therapeutic space: a Grendon debate. Prison Service Journal 187: 48-187.

Berger J (1972) Ways of Seeing. London: BBC and Penguin Books.

Birkbeck C and Perez-Santiago N (2006) The character of penal control in Latin America: Sentence remissions in a Venezuelan prison. Criminology \& Criminal Justice 6(3): 289308.

Bissell D (2007) Animating suspension: waiting for mobilities. Mobilities 2(2): 277-298.

Brown A (1998) 'Doing Time': the Extended Present of the Long-Term Prisoner. Time and Society 7: 93-103.

Carlen P (Ed) (2008) Imaginary Penalities. Cullompton: Willan Publishing.

Cohen S and Taylor L (1972) Psychological Survival: Experience of Long-term Imprisonment. London: Penguin Books Ltd.

Deleuze G (1992) Postscript on Control Societies. October 59(Winter): 3-7.

Drake D (2014) Prisons, Punishment and the Pursuit of Security. Basingstoke: Palgrave Macmillan.

Eldridge J (2014) Stretching Exercises: Stimulating the Sociological Imagination. John Eldridge Festschrift Conference, University of Glasgow, 16-17 September 2014. Available at: https://eldridgeconference2014.wordpress.com/

Elliot A (2014) Paused subjects: waiting for migration in North Africa. [under review for special section on waiting, Time \& Society]

Foucault M (1995) Discipline and Punish, $2^{\text {nd }}$ edition. New York: Vintage Books. 
Gasparini G (1995) On waiting. Time \& Society 4(1): 29-45.

Geunther L (2013) Solitary Confinement: Living Death and Its Afterlives. Minneapolis: University of Minnesota Press.

Gill N (2013) Mobility vs. liberty? The punitive uses of movement with and outside carceral environments. In: Moran D, Gill N \& Conlon D (Eds) Carceral spaces: mobility and agency in imprisonment and migrant detention. Surrey: Ashgate, pp. 19-36.

Goffman, E (1961) Asylums: Essays on the Social Situation of Mental Patients and Other Inmates. New York: Anchor Books.

Hage G (2009) Introduction. In: Hage G (Ed.) Waiting Melbourne: University of Melbourne Press, pp. 1-14.

Hiemstra N (2013) 'You don't even know where you are': chaotic geographies of US migrant detention and deportation. In: Moran D, Gill N \& Conlon D (Eds) Carceral spaces: mobility and agency in imprisonment and migrant detention. Surrey: Ashgate, pp. 5776.

ledema R, Long D, Carroll K, Stenglin M, Braithwaite J (2006) Corridor work: How liminal space becomes a resource for handling complexities of multi-disciplinary health care. APROS 11: Asia-Pacific Researchers in Organization Studies: 11th International Colloquium. Asia-Pacific Researchers in Organisation Studies.

Jefferson A (2014) Conceptualizing confinement: prisons and poverty in Sierra Leone. Criminology and Criminal Justice 14(1): 44-60.

Kohn T (2009) Waiting on Death Row. In: Hage G (Ed) Waiting Melbourne: University of Melbourne Press, pp. 218-227.

Lakoff G and Johnson M (1980) Metaphors We Live By. Chicago: University of Chicago Press.

Lam A (2014) Televisual waiting: images of time and waiting in CSI. [under review for special section on waiting, Time and Society]

Mannochio D and Dunn J (1970) The Time Game: Two Views of a Prison. Sage Publications, Inc.

Martin T (2013) Embracing Human Rights: Governance and Transition in Ugandan Prisons. PhD Thesis, Roskilde University, manuscript on file with the author.

Matthews R (2009) Doing Time: An Introduction to the Sociology of Imprisonment, $2^{\text {nd }}$ edn. Basingstoke: Palgrave Macmillan.

Medlicott D (1999) Surviving in the time machine. Time and Society 8(2): 211-230.

Moran D Gill N and Conlon D (Eds) (2013) Carceral spaces: mobility and agency in imprisonment and migrant detention. Surrey: Ashgate. 
Miesenhelder T (1985) An essay on time and the phenomenology of imprisonment. Deviant Behavior 6(1): 39-56.

Pallot J and Piacentini L (2012) Gender, Geography and Punishment: The Experience of Women Prisoners in Carceral Russia. Oxford: Oxford University Press.

Phillips J (1998) Sade in the corridor. Nottingham French Studies 37(2): 26-36.

Pratt J (2000) The return of the wheelbarrow men; or, the arrival of postmodern penality? British Journal of Criminology 40(1): 127-145.

Reed A (2010) Hope on Remand. Journal of the Royal Anthropological Institute vol. 17: 527544.

Rhodes L (2004) Total Confinement: Madness and Reason in the Maximum Security Prison. Berkeley: University of California Press.

Riles A (2006) Introduction: In Response. In: Riles A (Ed) Documents. Ann Arbor, MI: University of Michigan Press.

Rothman D (2002) Discovering the Asylum, revised edition. Chicago: Aldine Transaction.

Rotter R (2014) Waiting in the asylum determination process: empty interlude or engaged activity? [under review for special section on waiting, Time \& Society]

Schön D (1993) Generative Metaphor. In: Ortony A (Ed) Metaphor and Thought, 2nd Edn. Cambridge: CUP.

Scottish Government (2012) Prison Population Statistics and Population Projections Scotland. Statistical Bulletin, Crime and Justice Series. Edinburgh: Scotland. Available at: http://www.scotland.gov.uk/Publications/2012/06/6972/downloads

Scottish Prison Service (SPS) (2013) Report of the Scottish Prison Service Organisational Review: Unlocking Potential, Transforming Lives. Edinburgh: SPS.

Scottish Prisons Commission (2008) Scotland's Choice: Report of the Scottish Prisons Commission. Edinburgh: Scottish Government.

Urry J (2007) Mobilities. Cambridge: Polity Press.

Wacquant L (2001) Deadly symbiosis: when ghetto and prison meet and mesh. Punishment and Society 3(1): 95-134.

Wahidin A (2006) Time and the Prison Experience. Sociological Research Online, 11.

Watts L \& Urry J (2008) Moving methods, travelling times. Environment and Planning D 26: 860-874. 
Yanow D (1998) Space stories: studying museum buildings as organizational spaces while reflecting on interpretive methods and their narration. Journal of Management Inquiry (7): 215-239. 